University of Vermont

UVM ScholarWorks

University Libraries Faculty and Staff

Publications

University Libraries

6-24-2016

\title{
Reviews of Science for Science Librarians: The Challenge of the Zika Virus: An Emerging Arbovirus Disease
}

Frances A. Delwiche

University of Vermont, fdelwich@uvm.edu

Follow this and additional works at: https://scholarworks.uvm.edu/libfacpub

Part of the Infectious Disease Commons, Library and Information Science Commons, Virology Commons, and the Virus Diseases Commons

Recommended Citation

Delwiche FA. Reviews of Science for Science Librarians: The Challenge of the Zika Virus: An Emerging Arbovirus Disease. Science \& Technology Libraries. 2016. DOI:10.1080/0194262X.2016.1192007

This Article is brought to you for free and open access by the University Libraries at UVM ScholarWorks. It has been accepted for inclusion in University Libraries Faculty and Staff Publications by an authorized administrator of UVM ScholarWorks. For more information, please contact scholarworks@uvm.edu. 


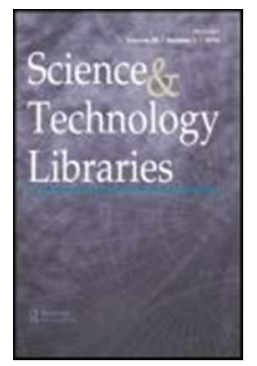

Review of Science for Science Librarians: The Challenge of the Zika Virus: An Emerging Arbovirus Disease

\begin{tabular}{|r|l|}
\hline Journal: & Science \& Technology Libraries \\
\hline Manuscript ID & WSTL-2016-0009.R1 \\
\hline Manuscript Type: & Reviews of Science \\
\hline Keywords: & Zika virus, arbovirus, microcephaly, Aedes aegypti, Guillain-Barre \\
\hline \multicolumn{2}{|c}{} \\
\hline
\end{tabular}

SCHOLARONE ${ }^{\mathrm{m}}$

Manuscripts 
Review of Science: Zika Virus

\title{
Review of Science for Science Librarians: \\ The Challenge of the Zika Virus: An Emerging Arbovirus Disease
}

\begin{abstract}
In early 2015, the previously obscure Zika virus swept into the Americas, seemingly coming from out of nowhere. With unprecedented speed and intensity, it raced across South and Central America, touching large portions of the population, and leaving in its wake unsettling reports of newborns suffering from devastating neurological disorders. By all accounts, this submicroscopic particle of miniscule size has somehow managed to take the local, regional, national, and international health authorities, as well as the public at large, entirely by surprise. Where did this virus come from? How is it transmitted? What type of illness does it cause? This paper seeks to answer these questions, and more. Following a brief synopsis of the present-day outbreak, it reviews the virology of the Zika virus, its modes of transmission, the nature of Zika Virus Disease, and current and future research endeavors that seek to increase our understanding of the virus.
\end{abstract}

\section{History}

The Zika virus is one of several emerging mosquito-borne viruses, including dengue, West Nile, and chikungunya, that have recently expanded their reach into the western hemisphere. The Zika virus (ZIKV) was first described in the medical literature as an incidental discovery made in 1947 in rhesus monkeys during a sylvatic yellow fever study in the Zika forest of Uganda (Dick, Kitchen, and Haddow 1952, Imperato 2016). Over the course of the next sixty years, a few small, isolated outbreaks of Zika Virus Disease in humans were reported, primarily in Africa and southeast Asia, together amounting to only 14 cases (Vasconcelos and Calisher 
Review of Science: Zika Virus

2016). In April 2007, the situation changed dramatically, as the first large-scale outbreak occurred on the Yap Islands of the Federated States of Micronesia. Nearly three quarters of the islands' 7391 residents were believed to have been infected, and upwards of 900 people became ill (Duffy et al. 2009). In 2013-2014, a more extensive outbreak occurred in French Polynesia, resulting in approximately 28,000 cases (Musso, Nilles, and Cao-Lormeau 2014). From there, the virus cropped up in the Cook Islands, Easter Island, New Caledonia, the Solomon Islands, and other Pacific islands (Musso 2015).

\section{Current Outbreak in the Americas}

In late 2014, the Zika virus first emerged in Brazil (Kleber de Oliveira et al. 2016), presumably stemming from the 2014 Va'a World Sprint Championship canoe race held in Rio de Janeiro, which reportedly included participants from ZIKV infected areas of French Polynesia (Musso 2015, Gautret and Simon 2016). Finding abundant breeding grounds for its mosquito vector in the densely populated urban environments of Brazil, and an immunologically naïve host population, the virus was able to spread rapidly northward and westward over the course of the next year, reaching Mexico by November 2015 (Gatherer and Kohl 2016), Puerto Rico by December 2015 (Thomas et al. 2016), and threatening to reach continental United States in 2016. As of May 05, 2016, locally acquired (autochthonous) vector-borne transmission of the Zika virus had been confirmed in 38 countries and territories in the Region of the Americas (Pan American Health Organization 2016b). (Figs. 1 and 2).

$<$ Insert Figures 1 and 2 here $>$

In the United States, according to the Centers for Disease Control and Prevention (CDC), 153 cases of Zika Virus Disease had been reported as of March 02, 2016; a month later, that 
number had jumped to 312 ; and two months later, 472 cases had been reported, all of which were travel-associated. As of May 04, 2016, no autochthonous mosquito-borne cases of ZIKV had been documented in the United States. However, in the US territories, the situation was quite the reverse. As of May 04, 2016, 661 cases were reported in American Samoa, Puerto Rico, and the US Virgin Islands, including $3(0.5 \%)$ travel-associated cases and $658(99.5 \%)$ autochthonous cases, of which 629 (95.6\%) occurred in Puerto Rico (Centers for Disease Control and Prevention 2016). The most up to date epidemiological information on the Zika virus outbreak in the Americas can be found by consulting the resources listed in Table 1.

$<$ Insert Table 1 here $>$

The current outbreak is the result of a complex interplay of factors involving virus/vector/host relationships, many of which are not yet fully understood. The wide distribution of the primary vector Aedes aegypti, increased international air travel, and the densely populated urban areas of Central and South America with less than optimal sanitation are likely contributors (Imperato 2016). The strong El Niño weather pattern and record warm temperatures that affected Brazil in the latter half of 2015 may have contributed to the rapid spread of the Zika virus by providing conditions favorable to its mosquito vector (Paz and Semenza 2016). Adaptive changes made by the Zika virus making it more pathogenic or better able to be transmitted by new arthropod vectors may also be contributing factors (Costa et al. 2016).

\section{Virology}

The Zika Virus (ZIKV) is an arthropod-borne virus ("arbovirus") of the family Flaviviridae, genus Flavivirus, a group of positive-sense, single-stranded RNA (+ssRNA) viruses that includes the dengue, yellow fever, West Nile, and the Japanese encephalitis viruses. 
Review of Science: Zika Virus

(Table 2) ZIKV is relatively small, measuring approximately $40 \mathrm{~nm}$ (Nierenberg 2016), enveloped, and icosahedral in shape. (Fig 3) It has a non-coding region at the $5^{\circ}$ and $3^{\circ}$ ends, and a single open reading frame (ORF) that encodes for a polyprotein, which is cleaved posttranslationally into multiple structural and non-structural proteins (Faye et al. 2014).

$<$ Insert Fig. 3 here $>$ $<$ Insert Table 2 here $>$

Upon injection of the virus into the skin of the human host, a complicated sequence of events occurs at the molecular level, leading to attachment and entry of the virus into target cells, and ultimately hijacking of the host's cellular machinery by the virus for its own replication. Consistent with its primary mode of transmission, human dermal fibroblasts, epidermal keratinocytes, and dendritic cells in the skin have been shown to be highly permissive to infection with ZIKV; additionally, the virus has been found to induce the production of autophagosomes in infected fibroblasts, possibly as a means of promoting viral replication (Hamel et al. 2015). After replication in skin cells, the virus disseminates via the lymphatics and blood stream to other parts of the body, including the CNS, heart, skeletal muscles, and possibly crossing the placenta to reach the developing fetus (Chan et al. 2016). The exact target cells of ZIKV are not yet known, though various studies suggest neurological cells may be chief among them. A 1952 study in mice showed the Zika virus to be highly neurotropic (Dick 1952); an in vitro model indicated that human cortical neural progenitors are readily infected by ZIKV (Tang et al. 2016); and an in vitro model mimicking brain development in the first trimester demonstrated that ZIKV induces cell death in cultured neural stem cells (Garcez et al. 2016). There are two primary strains of ZIKV, African and Asian. Phylogenetic studies indicate that the strain implicated in the 2015-2016 outbreak in Brazil is essentially identical with the 
Review of Science: Zika Virus

strain that caused the 2013-2014 French Polynesia outbreak, and is of Asian lineage (Zanluca et al. 2015, Musso 2015).

\section{Arthropod-borne Transmission}

The principal mode of transmission of ZIKV to humans is through the bite of an infected mosquito. The arthropod vector most frequently implicated in the transmission of ZIKV is the female Aedes aegypti mosquito, which also transmits dengue, yellow fever, and chikungunya. The Aedes aegypti mosquito secured its place in the annals of history when, at the turn of the $20^{\text {th }}$ century, it became the object of intense research by Dr. Carlos Juan Finlay, Dr. Jesse William Lazear, Major Walter Reed, and others in their heroic efforts to conquer yellow fever.

The Aedes aegypti mosquito is notable in that it feeds throughout the day, prefers humans as the source of its blood meals, and feeds both indoors and outdoors. Over the millennia, this species of mosquito has adapted to coexist with humans, developing a predilection for breeding in small pools of stagnant water such as those found in artificial containers in and around areas of human habitation (Fauci and Morens 2016). These may include water transport and storage containers, old tires, trash bins, flower pots, and discarded plastic containers, as well as wet areas inside the home. Eggs laid by the Aedes mosquito are hardy, being able to survive for as long as a year without water, readily hatching once water becomes available (World Health Organization 2016b).

In urban settings, humans develop a sufficiently high level of viremia to enable them to serve as the primary vertebrate host for ZIKV, resulting in an urban transmission cycle. Thus, residents of densely settled, resource-poor regions within the vector's geographic range where indoor and outdoor sanitation may be sub-standard are at risk for ZIKV infections. In Africa and 
Review of Science: Zika Virus

Asia, ZIKV is believed to be maintained in a sylvatic cycle between mosquito and non-human primates, probably monkeys (Lazear and Diamond 2016, Zanluca and Duarte Dos Santos 2016). Antibodies to the virus have been detected in various large mammals and rodents, but it is not known whether these animals serve as reservoirs (Zanluca and Duarte Dos Santos 2016).

In the United States, the geographic range of Aedes aegypti extends into the southeastern part of the country, making it feasible that vector-borne autochthonous cases will occur in states such as Florida, Texas, and Louisiana. However, ZIKV is also transmitted by several other Aedes species, including Aedes albopictus (Chouin-Carneiro et al. 2016), which notably has a more northerly geographic range that extends well into the central and eastern part of the country (Kraemer et al. 2015).

If the ZIKV genome is able to make adaptive changes to improve the effectiveness of the A. albopictus mosquito as a vector, as occurred with the chikungunya virus, it could move into areas lacking $A$. aegypti, potentially bringing the virus to much of the US, as well as to Canada, Chile, and parts of Europe and Asia (Gardner, Chen, and Sarkar 2016, Stein 2016, Petersen and Busch 2010). The virus has been recovered from other mosquito genera as well, such as Anopholes, Culex, and Mansonia (Ayres 2016), though again it is not clear whether they are able to serve as competent vectors (Gardner, Chen, and Sarkar 2016).

\section{Non-arthropod-borne Transmission}

The potential for vertical transmission from mother to child emerged as a major global health concern in the $2015-2016$ outbreak due to the observed increase in microcephaly in fetuses/newborns of mothers who had been infected with ZIKV during pregnancy (Kleber de Oliveira et al. 2016). Microcephaly has been traditionally defined as an abnormally small head 
Review of Science: Zika Virus

that is more than 2 standard deviations (SDs) below the mean for the age and sex of the child (Weaver 1999). In Brazil, the national live birth registry applied a stricter definition for microcephaly as being $>=3$ SDs for age and sex (Kleber de Oliveira et al. 2016).

Temporal and circumstantial evidence has been reported for the transplacental transmission of ZIKV and its association with microcephaly. Amniotic fluid from two pregnant women in Brazil with past exposure to ZIKV who were diagnosed with fetal microcephaly was shown to be positive for the Zika virus (Oliveira Melo et al. 2016), and autopsy results of a microcephalic fetus of a woman who was presumed to have had a ZIKV infection at 13 weeks' gestation showed ZIKV in the brain tissues (Mlakar et al. 2016).

The mechanisms by which ZIKV may cause microcephaly and other neurological defects are not yet clear. The virus could cross the placental barrier and infect the fetus directly, as occurs with rubella and cytomegalovirus (Mor 2016). Alternatively, the virus may induce an inflammatory response in the placenta, or it may disrupt the production by the placenta of particular genes, molecules, or pathways, which in turn may adversely affect fetal brain development (Adibi et al. 2016, Mor 2016).

Sexual transmission has been confirmed in a small number of cases in the US and elsewhere as a result of sexual contact with men returning from travel to Zika-infected areas who experienced symptoms consistent with ZIKV Infection (Foy et al. 2011, McCarthy 2016, Oster et al. 2016). The semen of a man who contracted a ZIKV infection in the 2013-2014 French Polynesia outbreak tested positive for the virus on reverse transcriptase polymerase chain reaction (RT-PCR) two weeks after recovering from the illness (Musso, Roche, Robin, et al. 2015). In a 2014 travel-associated case in the United Kingdom, semen from a man tested positive for ZIKV at 27 and 62 days after onset of illness (Atkinson 2016). Both cases raise concerns 
Review of Science: Zika Virus

about the long-term persistence of ZIKV in semen and a possible post-recovery carrier state. The risk of sexual transmission is of particular concern if the female partner is pregnant, as the virus could possibly be transmitted to the fetus.

Other possible routes of transmission, such as saliva, urine, respiratory droplets, breast milk, vaginal delivery, mucocutaneous exposure, hemodialysis, and organ transplantation, cannot be ruled out (Chan et al. 2016).

Transmission of ZIKV through blood transfusion is a credible risk, given the asymptomatic viremia that occurs early in the infection, the high rate of asymptomatic cases, and the high incidence of infection that occurs among immunologically naïve populations during massive outbreaks (Marano et al. 2015, Petersen and Busch 2010). In the 2013-2014 outbreak in French Polynesia, 2.8\% (42/1505) of asymptomatic blood donors tested positive for ZIKV on RT-PCR, and 26.2\% (11/42) of those reported a Zika-like illness 3-10 days after donating blood (Musso et al. 2014).

In lieu of a blood donor screening test for ZIKV for use by blood collection centers, the US Food and Drug Administration has issued the following guidelines for blood donations. In areas with no active ZIKV transmission, a 4-week deferral period is recommended for donors deemed to be at risk for Zika infection, and in areas with active transmission, it is recommended that blood and blood products be obtained from outside the region (Marks, Epstein, and Borio 2016).

However, in geographically isolated areas, it may be impractical or impossible to obtain blood from another region. Such was the case during the 2013-2014 French Polynesia outbreak, prompting local health authorities to grant permission for use of RT-PCR to screen locally donated blood, coupled with pathogen inactivation for selected blood products (Musso et al. 
Review of Science: Zika Virus

2014). In the future, it is hoped that pathogen reduction techniques will be developed that could be applied to all blood products, thereby reducing the need for the battery of expensive screening tests currently in use (Marks, Epstein, and Borio 2016).

\section{Zika Virus Infections}

In approximately $80 \%$ of cases, infection with the Zika virus is asymptomatic or very mild, with only about $20 \%$ of those infected actually becoming ill (Centers for Disease Control and Prevention 2016a). Those who become symptomatic, do so following an incubation period of 2-14 days (Chan et al. 2016, Rudolph et al. 2014), with a systemic febrile rash illness similar to dengue or chikungunya. The current PAHO/WHO definition for a suspected case of Zika Virus Disease is a patient with rash, plus two or more of the following symptoms: fever, conjunctivitis, arthralgia, myalgia, and peri-articular edema (Pan American Health Organization 2016a). Other symptoms that have been reported include headache, fatigue, malaise, chills, retroorbital pain, paresthesia, lymphadenopathy, edema, diarrhea, nausea, vomiting, abdominal pain, sore throat, dizziness, and dysuria (Brasil et al. 2016, Chan et al. 2016).

Since fever is not always a presenting symptom, use of the term "Zika Fever" is discouraged. In fact, a 2016 report of ZIKV infections in pregnant women in Brazil showed that whereas maculopapular rash, conjunctivitis, and lymphadenopathy were clinically significant features, fever was present in only $28 \%$ of the cases (Brasil et al. 2016). However, other studies showed higher numbers: in a retrospective study of 2015 data from Brazil, 67\% of patients had fever (Cerbino-Neto J 2016), and a study from Puerto Rico in 2015-2016 showed that 73\% had fever (Thomas et al. 2016). 
Review of Science: Zika Virus

The majority of ZIKV illnesses are self-limiting, with most symptoms resolving within 37 days. Because of the high rate of asymptomatic infection, non-specific symptomology, resemblance to other arbovirus infections, and possible co-infections with other endemic viruses such as dengue or chikungunya, many cases of ZIKV infection are probably undiagnosed or misdiagnosed.

\section{Complications of Zika Virus Infections}

Despite the mild nature of the disease and high rate of asymptomatic cases, Zika virus infections are of concern because of their suspected association with microcephaly and other neurological abnormalities. In the 2013-2014 outbreak in French Polynesia, perinatal transmission, either transplacentally or during delivery, was reported (Besnard et al. 2014), and a retrospective analysis of the data suggested that exposure to ZIKV by pregnant women in the first trimester was associated with an increased risk of microcephaly (Cauchemez et al. 2016). In Nov 2015, a nearly 20-fold increase in the incidence of microcephaly was reported in Brazil, with 99.7cases/100,000 live births, versus 5.5 cases/100,000 live births in 2000 (Pan American Health Organization 2015). Between Jan 01, 2015 and Jan 07, 2016, a total of 574 cases of microcephaly were identified in Brazil, compared with an average of 157 cases per year for the years 2000-2014 (Kleber de Oliveira et al. 2016). ZIKV infections contracted during the first trimester of pregnancy appear to be associated with an increased risk of microcephaly (Cauchemez et al. 2016, Kleber de Oliveira et al. 2016), though fetal abnormalities have been reported following ZIKV infections during any week of gestation (Brasil et al. 2016). 
Along with a small head circumference, congenital microcephaly is characterized by a heterogeneous range of clinical findings, including facial disproportionality, excess skin scalp folds, hypertonia or spasticity, tremors, hearing and visual abnormalities, umbilical hernia, clubfoot, arthrogryposis, and more (Miranda-Filho et al. 2016). Zika virus infections during pregnancy were found to be associated with intrauterine growth restriction, cerebral calcifications, placental insufficiency, and oligo- or anhydramnios (Brasil et al. 2016). In a small study of microcephalic newborns, various ocular defects were found, including optic nerve alterations and macular abnormalities, especially foveal reflex loss (Ventura et al. 2016).

In addition to congenital complications, Zika infections have been associated with an increased incidence of Guillain-Barre Syndrome (GBS), a rare acute inflammatory autoimmune neuritis that is frequently triggered by a preceding viral or bacterial infection (Cao-Lormeau et al. 2016). In the 2013-2014 Zika outbreak in French Polynesia, forty-two cases of Guillain-Barre Syndrome (GBS) were reported, representing a 20 -fold increase over the previous four years (Cao-Lormeau et al. 2016, Oehler et al. 2014, World Health Organization 2016c). In the current outbreak, an increased incidence of GBS has been reported in Brazil, El Salvador, Suriname, and Venezuela, and cases of GBS with confirmed ZIKV infection have been reported in Columbia, Dominican Republic, Honduras, Puerto Rico, Haiti, and Martinique (World Health Organization 2016c). It is thought that the unusual spike in GBS cases both in French Polynesia and in the Americas may be due to co-infections with dengue and ZIKV, and/or consecutive arbovirus infections (Zika Virus Infection, 2016).

On Feb 01, 2016, the World Health Organization (WHO) declared a Public Health Emergency of International Concern (PHEIC) due to concern over the possibility of an association between ZIKV infections and microcephaly, GBS, and other neurological disorders 
(World Health Organization 2016a). On April 07, 2016, the WHO issued a statement saying that "Based on a growing body of preliminary research, there is scientific consensus that Zika virus is a cause of microcephaly and Guillain-Barré syndrome" (World Health Organization 2016c).

From a societal and sociological standpoint, numerous immediate and long-term repercussions of the current ZIKV outbreak are becoming apparent. Counseling will be required for pregnant women who contract a ZIKV infection, especially during the first trimester. Intensive care treatment for patients struck by Guillain-Barre Syndrome will be crucial, as will long-term treatment of newborns with microcephaly and other neurological abnormalities. Patients will need multidisciplinary support and ongoing medical care, incurring a substantial burden to individuals, families, and communities. These factors will have serious long-term implications for overall health policy, especially in resource-poor regions.

\section{Laboratory Diagnosis}

Currently, there is no rapid diagnostic test for ZIKV available for routine use in clinical laboratories or at the point of care. Therefore, diagnosis is often made on the basis of clinical presentation, travel history, and time spent in an area of active ZIKV transmission, keeping in mind that the disease may mimic or coexist with other endemic infections. For confirmation of ZIKV infections, the most accurate test currently available is the reverse transcriptase polymerase chain reaction (RT-PCR), which detects the presence of Zika viral RNA in serum, plasma, or other body fluids. Several RT-PCR assays have been developed, including one designed by the CDC that uses "two one-step real-time RT-PCR (rRT-PCR) reactions targeting the ZIKV premembrane (prM) and envelope (E) genes, respectively", as well as other assays that target various non-structural proteins such as NS1, NS3, and NS5 (Waggoner and Pinsky 2016). 
Review of Science: Zika Virus

Other methods for laboratory diagnosis of ZIKV include serologic testing for IgM antibodies using enzyme-linked immunosorbent assays (ELISA), coupled with plaque-reduction neutralization tests (PRNT) to determine neutralizing antibody titers (Duffy et al. 2009). Crossreactivity with other flaviviruses, especially the dengue virus, with which ZIKV often co-exists, can make interpretation of ELISA test results difficult. This is particularly true when ZIKV is a secondary flavivirus infection, or in populations with background immunity to other flaviviruses (Lanciotti et al. 2008). Nevertheless, in suspected cases of Zika virus infection, a positive ELISA test for Zika IgM antibodies, coupled with sufficiently high PRNT titers and in the absence of other flaviviruses, is considered confirmatory for ZIKV (Pan American Health Organization 2016a).

The period of viremia with ZIKV infections is believed to be relatively brief, approximately 3-5 days after the onset of symptoms (Waggoner and Pinsky 2016), reflecting the ideal time frame for collecting blood samples for diagnosis of acute ZIKV infections. This can be challenging, given the non-specific nature of the symptoms and lack of a clear onset of illness. However, urine may prove to be a suitable alternative, as the RNA load in urine has been found to be higher than in serum and is detectable for a longer period of time, and, as a laboratory specimen, it is less invasive to collect (Gourinat et al. 2015). Saliva may also prove to be a useful substitute or adjunct for acute phase diagnosis, especially in pediatric patients, as it will sometimes test positive for ZIKV when a concurrent serum sample tests negative (Musso, Roche, Nhan, et al. 2015). In the future, it is hoped that diagnostic tests will be developed that are able to detect multiple arbovirus infections, such as Zika, dengue, and chikungunya, simultaneously (Waggoner and Pinsky 2016). 
Review of Science: Zika Virus

Laboratory diagnosis may also be obtained through viral culture, though this method is generally reserved for use in research laboratories and public health facilities (Waggoner and Pinsky 2016).

\section{Treatment}

Currently, there is no treatment available specifically for ZIKV infections. Therefore, treatment consists primarily of supportive care, including rest and fluids, plus antihistamines and acetaminophen for symptom relief. The use of aspirin is not recommended due to the risk of bleeding or Reye's Syndrome, nor is the use of other non-steroidal anti-inflammatory drugs (NSAIDS), as they are contraindicated in cases of dengue or chikungunya, with which Zika infections may coexist (Pan American Health Organization 2015).

\section{Prevention}

Since there is currently no vaccine for ZIKV, prevention of ZIKV infections is primarily focused on averting arthropod-borne transmission of the infectious agent, both through reducing the population of mosquitoes, and reducing contact between mosquitoes and humans (World Health Organization 2016b). At the individual level, the use of protective clothing and an Environmental Protection Agency (EPA)-registered insect repellent, such as DEET, picaridin, IR3535, oil of lemon eucalyptus, or para-menthane-diol, is recommended (Centers for Disease Control and Prevention 2016a). For patients who become symptomatic, it is particularly important to avoid mosquito bites during the first week of illness to prevent transmission of the virus to others during the viremic period. 
Within the household, small pools of standing water in and around the home should be eliminated to reduce mosquito breeding habitat. Water storage receptacles and artificial containers should be emptied or covered, and bathing, cooking, and laundry areas should be kept as dry as possible. Since the Aedes mosquito bites throughout the day, both indoors and out, the installation of securely fitting window and door screens on homes, and the use of bed nets is advised. These measures are especially important for pregnant women, or those who might become pregnant, in order to prevent possible perinatal transmission.

At the community level, aggressive vector control will serve to disrupt the urban transmission cycle between infected humans, the mosquito vector, and susceptible humans. Efforts should be made to reduce the density of mosquitoes in the locality, and during outbreaks, the spraying of insecticides may be advised (World Health Organization 2016b). Public education campaigns conducted in schools, churches, clinics, stores, and businesses in regions of active transmission will help to raise public awareness of the risks and symptoms of ZIKV infections. Health care professionals are advised to remain alert for signs and symptoms of ZIKV infection among their patients, and whenever possible, provide ultrasound and other diagnostics to pregnant women who may have been exposed. Data and information sharing between communities, and enhanced surveillance at the national and international level, will further contribute to the global prevention and control of widespread ZIKV outbreaks.

In response to studies demonstrating the sexual transmission of ZIKV, the CDC has issued an interim guideline for couples in which a man lives in or has recently traveled to an area of active transmission (Oster et al. 2016). In addition, the CDC has issued a number of guidelines directed at specific populations, including pregnant women and pregnant travelers, and health care providers caring for pregnant women and infants and children. Since these guidelines are 
Review of Science: Zika Virus

subject to revision as more information about ZIKV becomes available, the CDC website (www.cdc.gov) should be consulted for the most current recommendations.

\section{Future Perspectives}

The two previous large-scale outbreaks of the Zika virus, which occurred in the Yap Islands in 2007 and French Polynesia in 2013-2014, abated after roughly a year. Though it is too early to determine whether the current outbreak in the Americas will follow the same pattern, it is already clear that this event has exacted a heavy toll on the populations it has affected. In spite of, or perhaps because of, the enormous challenges it has presented, this outbreak has triggered a dramatic increase in our overall understanding of this emerging disease. Indeed, the number of scholarly publications published on the Zika virus has multiplied exponentially in the past year, as the medical and scientific communities struggle to understand this mysterious illness and its sequelae. Yet, there remains much to be learned.

Research initiatives are proceeding apace on multiple fronts, both at the basic science and clinical level, focusing on all aspects of the virus/vector/host triad. The National Science Foundation recently announced an invitation for research proposals to address the ecological transmission dynamics of the Zika virus, including the non-human hosts of ZIKV, transmission rate of ZIKV between vectors/carriers and humans, and the rate of spread of ZIKV worldwide (National Science Foundation 2016).

The mosquito vector itself has been, and will continue to be, the subject of active research. Mosquito resistance to insecticides has long been the subject of research in the context of malaria and other arbovirus diseases, and will have clear implications for ZIKV transmission. Studies on the effect of global climate change on the lifespan and geographic ranges of vector 
mosquitoes, and how these factors will affect the transmission of ZIKV, are also underway. Recently, a small biotech company, originally launched by Oxford University in 2002, has taken mosquito research to a whole new level. It has developed a genetically engineered male mosquito called OX513A that carries a lethal gene which, when mated with female wild mosquitos, will cause the offspring to die. The company, now owned by biotech giant Intrexon, has field tested the mosquito in the Cayman Islands, Panama, and Brazil, and hopes to employ it in Florida in the near future, pending FDA approval (LaMotte 2016).

Complementing these initiatives, the National Institute of Allergy and Infectious Diseases (NIAID), has invited proposals for projects covering a wide range of basic science and clinical aspects of ZIKV and Zika Virus Disease (National Institute of Allergy and Infectious Diseases). (Table 3)

\section{$<$ Insert Table 3 here $>$}

Though information gained from each of these research foci will be essential for building the overall knowledgebase of Zika, research in three areas in particular is urgently needed. First, it is critically important that the mechanism by which the Zika virus causes congenital neurological abnormalities be elucidated, in order to prevent the development of devastating birth defects. Secondly, an affordable, rapid, and reliable diagnostic test for ZIKV for use in clinical environments is vital to enable the timely and accurate diagnosis of Zika infections. Finally, the development of a safe and effective vaccine against ZIKV is a clear priority, as it may well prove to be the world's best hope for conquering this new disease. Yet the development of a vaccine for any infectious disease is no trivial matter. At best, it can take years, perhaps decades, to come to fruition. At worst, the efforts will sputter and stall, only to languish as unfunded, orphan initiatives. 
Review of Science: Zika Virus

Undaunted, the challenge of developing a ZIKV vaccine has been taken up by multiple entitles, including universities, pharmaceutical companies, private research institutes, and government bodies, as described in a recent article in Science (Cohen 2016). For example, NewLink Genetics of Massachusetts, USA, is working to develop a traditional-style vaccine using an inactivated virus. The advantage of this type of vaccine is that it may be more likely to be approved for use in pregnancy. Researchers at the Butantan Institute of São Paulo, Brazil are investigating use of an attenuated live vaccine made with a technology similar to that used by the NIAID for its dengue vaccine. The technology used by the NIAID for its West Nile vaccine may be yet another option. This involves the insertion of a circular DNA plasmid containing specific ZIKV genes into bacterial cells, resulting in the production of "virus-like particles" that will elicit an immune response similar to that of inactivated vaccines (Cohen 2016).

Bypassing the need for a bacterial carrier cell altogether, Inovio Pharmaceuticals of Pennsylvania, USA is working to develop a vaccine using simply a plasmid containing Zika virus genes, which would be injected directly into the skin. Though this method can be used to produce a vaccine relatively quickly, in the past, it has been plagued by failure to launch a sufficiently strong immune response. Still another high-tech strategy is to insert the ZIKV genes into the genome of a harmless virus, which is similar to the approach used by GlaxoSmithKline for its recently developed Ebola vaccine (Cohen 2016).

Which of these strategies will eventually emerge as the industry leader(s) is anybody's guess at this point. The fervent hope of the general public and health authorities alike is that one of them will ultimately be successful in producing a vaccine capable of forestalling the next Zika pandemic. 
Review of Science: Zika Virus

\section{Conclusion}

Though once thought of merely as the source of a mild, unremarkable arboviral disease that was little cause for concern, the Zika virus has proven its ability to wreak havoc on a global scale. The medical and scientific community is still very early in the process of understanding the science of this disease and its clinical sequelae, and much of the information presented herein may already be outdated. As this event unfolds, we are witnessing the creation of medical history before our very eyes and observing the generation of scientific knowledge in real time, with new findings being revealed on almost a daily basis. May the lessons learned carry us forward, ready and prepared to meet the next emerging viral pandemic. 
Review of Science: Zika Virus

\section{REFERENCES}

Adibi, J. J., E. T. Marques, Jr., A. Cartus, and R. H. Beigi. 2016. Teratogenic Effects of the Zika Virus and the Role of the Placenta. Lancet 387 (10027): 1587-1590. doi: 10.1016/s01406736(16)00650-4.

Atkinson, B., P. Hearn, B. Afrough, S. Lumley, D. Carter, E. J. Aarons EJ, et al. 2016. Detection of Zika Virus in Semen. Emerging Infectious Diseases 22 (5). doi:

10.3201/eid2205.160107.

Ayres, C. F. 2016. Identification of Zika Virus Vectors and Implications for Control. Lancet. Infectious diseases. 16 (3): 278-279. doi: 10.1016/s1473-3099(16)00073-6.

Besnard, M., S. Lastere, A. Teissier, V. Cao-Lormeau, and D. Musso. 2014. Evidence of Perinatal Transmission of Zika Virus, French Polynesia, December 2013 and February 2014. Eurosurveillance 19 (13): pii: 20751.

Brasil, P., J. P. Pereira, Jr., C. Raja Gabaglia, L. Damasceno, M. Wakimoto, R. M. Ribeiro Nogueira, P. Carvalho de Sequeira, A. Machado Siqueira, L. M. Abreu de Carvalho, D. Cotrim da Cunha, G. A. Calvet, E. S. Neves, M. E. Moreira, A. E. Rodrigues Baiao, P. R. Nassar de Carvalho, C. Janzen, S. G. Valderramos, J. D. Cherry, A. M. Bispo de Filippis, and K. Nielsen-Saines. 2016. Zika Virus Infection in Pregnant Women in Rio De Janeiro - Preliminary Report. New England Journal of Medicine 374. doi: 10.1056/NEJMoa1602412.

Cao-Lormeau, V. M., A. Blake, S. Mons, S. Lastere, C. Roche, J. Vanhomwegen, T. Dub, L. Baudouin, A. Teissier, P. Larre, A. L. Vial, C. Decam, V. Choumet, S. K. Halstead, H. J. Willison, L. Musset, J. C. Manuguerra, P. Despres, E. Fournier, H. P. Mallet, D. Musso, A. Fontanet, J. Neil, and F. Ghawche. 2016. Guillain-Barre Syndrome Outbreak 
Review of Science: Zika Virus

Associated with Zika Virus Infection in French Polynesia: A Case-Control Study. Lancet 387 (10027): 1531-1539. doi: 10.1016/s0140-6736(16)00562-6.

Cauchemez, S., M. Besnard, P. Bompard, T. Dub, P. Guillemette-Artur, D. Eyrolle-Guignot, H.

Salje, M. D. Van Kerkhove, V. Abadie, C. Garel, A. Fontanet, and H. P. Mallet. 2016. Association between Zika Virus and Microcephaly in French Polynesia, 2013-15: A Retrospective Study. Lancet 387. doi: 10.1016/s0140-6736(16)00651-6.

Centers for Disease Control and Prevention (CDC). 2016. Zika Virus. http://www.cdc.gov/zika/index.html. Accessed 05/12/16.

Cerbino-Neto, J., E. C. Mesquita, T. M. L. Souza, V. Parreira, B. B. Wittlin, B. Durovni, et al. 2016. Clinical Manifestations of Zika Virus Infection, Rio De Janeiro, Brazil, 2015. Emerging Infectious Diseases 22 (7). doi:10.3201/eid2207.160375.

Chan, J. F., G. K. Choi, C. C. Yip, V. C. Cheng, and K. Y. Yuen. 2016. Zika Fever and Congenital Zika Syndrome: An Unexpected Emerging Arboviral Disease? Journal of Infection 72 (5): 507-24. doi: 10.1016/j.jinf.2016.02.011.

Chouin-Carneiro, T., A. Vega-Rua, M. Vazeille, A. Yebakima, R. Girod, D. Goindin, M. Dupont-Rouzeyrol, R. Lourenco-de-Oliveira, and A. B. Failloux. 2016. Differential Susceptibilities of Aedes Aegypti and Aedes Albopictus from the Americas to Zika Virus. PLoS Neglected Tropical Diseases 10 (3):e0004543. doi: 10.1371/journal.pntd.0004543.

Cohen, J. 2016. Infectious Disease. The Race for a Zika Vaccine Is On. Science 351 (6273):5434. doi: 10.1126/science.351.6273.543.

Costa, F., M. Sarno, R. Khouri, B. de Paulo Freitas, I. Siqueira, G. S. Ribeiro, H. C. Ribeiro, G. S. Campos, L. C. Alcantara, M. G. Reis, S. C. Weaver, N. Vasilakis, A. I. Ko, and A. R. 
Review of Science: Zika Virus

Almeida. 2016. Emergence of Congenital Zika Syndrome: Viewpoint from the Front Lines. Annals of Internal Medicine. doi: 10.7326/m16-0332.

Dick, G. W., S. F. Kitchen, and A. J. Haddow. 1952. Zika Virus. I. Isolations and Serological Specificity. Transactions of the Royal Society of Tropical Medicine and Hygiene 46 (5):509-20.

Dick, G. W. 1952. Zika Virus. II. Pathogenicity and Physical Properties. Transactions of the Royal Society of Tropical Medicine and Hygiene 46 (5):521-34.

Duffy, M. R., T. H. Chen, W. T. Hancock, A. M. Powers, J. L. Kool, R. S. Lanciotti, M. Pretrick, M. Marfel, S. Holzbauer, C. Dubray, L. Guillaumot, A. Griggs, M. Bel, A. J. Lambert, J. Laven, O. Kosoy, A. Panella, B. J. Biggerstaff, M. Fischer, and E. B. Hayes. 2009. Zika Virus Outbreak on Yap Island, Federated States of Micronesia. New England Journal of Medicine 360 (24):2536-43. doi: 10.1056/NEJMoa0805715.

Fauci, A. S., and D. M. Morens. 2016. Zika Virus in the Americas--Yet Another Arbovirus Threat. New England Journal of Medicine 374 (7):601-4. doi: 10.1056/NEJMp1600297.

Faye, O., C. C. Freire, A. Iamarino, O. Faye, J. V. de Oliveira, M. Diallo, P. M. Zanotto, and A. A. Sall. 2014. Molecular Evolution of Zika Virus During Its Emergence in the 20th Century. PLoS Neglected Tropical Diseases 8 (1):e2636. doi: 10.1371/journal.pntd.0002636.

Foy, B. D., K. C. Kobylinski, J. L. Chilson Foy, B. J. Blitvich, A. Travassos da Rosa, A. D. Haddow, R. S. Lanciotti, and R. B. Tesh. 2011. Probable Non-Vector-Borne Transmission of Zika Virus, Colorado, USA. Emerging Infectious Diseases 17 (5):880-2. doi: 10.3201/eid1705.101939. 
Review of Science: Zika Virus

Garcez, P. P., E. C. Loiola, R. Madeiro da Costa, L. M. Higa, P. Trindade, R. Delvecchio, J. M. Nascimento, R. Brindeiro, A. Tanuri, and S. K. Rehen. 2016. Zika Virus Impairs Growth in Human Neurospheres and Brain Organoids. Science. doi: 10.1126/science.aaf6116.

Gardner, L. M., N. Chen, and S. Sarkar. 2016. Global Risk of Zika Virus Depends Critically on Vector Status of Aedes Albopictus. Lancet. Infectious Diseases. doi: 10.1016/s14733099(16)00176-6.

Gatherer, D., and A. Kohl. 2016. Zika Virus: A Previously Slow Pandemic Spreads Rapidly through the Americas. Journal of General Virology 97 (2):269-73. doi: 10.1099/jgv.0.000381.

Gautret, P., and F. Simon. 2016. Dengue, Chikungunya and Zika and Mass Gatherings: What Happened in Brazil, 2014. Travel Medicine and Infectious Disease 14 (1):7-8. doi: 10.1016/j.tmaid.2015.12.004.

Gourinat, A. C., O. O'Connor, E. Calvez, C. Goarant, and M. Dupont-Rouzeyrol. 2015. Detection of Zika Virus in Urine. Emerging Infectious Diseases 21 (1):84-6. doi: 10.3201/eid2101.140894.

Hamel, R., O. Dejarnac, S. Wichit, P. Ekchariyawat, A. Neyret, N. Luplertlop, M. Perera-Lecoin, P. Surasombatpattana, L. Talignani, F. Thomas, V. M. Cao-Lormeau, V. Choumet, L. Briant, P. Despres, A. Amara, H. Yssel, and D. Misse. 2015. Biology of Zika Virus Infection in Human Skin Cells. Journal of Virology 89 (17):8880-96. doi: 10.1128/jvi.00354-15.

Imperato, P. J. 2016. The Convergence of a Virus, Mosquitoes, and Human Travel in Globalizing the Zika Epidemic. Journal of Community Health. doi: 10.1007/s10900-0160177-7. 
Review of Science: Zika Virus

Kleber de Oliveira, W., J. Cortez-Escalante, W. T. De Oliveira, G. M. do Carmo, C. M. Henriques, G. E. Coelho, and G. V. Araujo de Franca. 2016. Increase in Reported Prevalence of Microcephaly in Infants Born to Women Living in Areas with Confirmed Zika Virus Transmission During the First Trimester of Pregnancy - Brazil, 2015. MMWR. Morbidity and Mortality Weekly Report 65 (9):242-7. doi: 10.15585/mmwr.mm6509e2.

Kraemer, M. U., M. E. Sinka, K. A. Duda, A. Q. Mylne, F. M. Shearer, C. M. Barker, C. G. Moore, R. G. Carvalho, G. E. Coelho, W. Van Bortel, G. Hendrickx, F. Schaffner, I. R. Elyazar, H. J. Teng, O. J. Brady, J. P. Messina, D. M. Pigott, T. W. Scott, D. L. Smith, G. R. Wint, N. Golding, and S. I. Hay. 2015. The Global Distribution of the Arbovirus Vectors Aedes Aegypti and Ae. Albopictus. eLife 4:e08347. doi: 10.7554/eLife.08347.

LaMotte, S. Stopping Zika: The GMO Mosquito That Kills His Own Offspring. CNN. 03/11/16. http://www.cnn.com/2016/03/07/health/zika-florida-gmo-mosquito/ Accessed 03/23/16.

Lanciotti, R. S., O. L. Kosoy, J. J. Laven, J. O. Velez, A. J. Lambert, A. J. Johnson, S. M. Stanfield, and M. R. Duffy. 2008. Genetic and Serologic Properties of Zika Virus Associated with an Epidemic, Yap State, Micronesia, 2007. Emerging Infectious Diseases 14 (8):1232-9. doi: 10.3201/eid1408.080287.

Lazear, H. M., and M. S. Diamond. 2016. Zika Virus: New Clinical Syndromes and Its Emergence in the Western Hemisphere. Journal of Virology. doi: 10.1128/jvi.00252-16.

Marano, G., S. Pupella, S. Vaglio, G. M. Liumbruno, and G. Grazzini. 2015. Zika Virus and the Never-Ending Story of Emerging Pathogens and Transfusion Medicine. Blood Transfusion 14 (2): 95-100. doi: 10.2450/2015.0066-15. 
Review of Science: Zika Virus

Marks, P. W., J. S. Epstein, and L. Borio. 2016. Maintaining a Safe Blood Supply in an Era of Emerging Pathogens. The Journal of Infectious Diseases. doi: 10.1093/infdis/jiw089.

McCarthy, M. 2016. Zika Virus Was Transmitted by Sexual Contact in Texas, Health Officials Report. BMJ 352:i720. doi: 10.1136/bmj.i720.

Miranda-Filho, D. B., C. M. Martelli, R. A. Ximenes, T. V. Araujo, M. A. Rocha, R. C. Ramos, R. Dhalia, R. F. Franca, E. T. Marques Junior, and L. C. Rodrigues. 2016. Initial Description of the Presumed Congenital Zika Syndrome. American Journal of Public Health 106 (4):598-600. doi: 10.2105/ajph.2016.303115.

Mlakar, J., M. Korva, N. Tul, M. Popovic, M. Poljsak-Prijatelj, J. Mraz, M. Kolenc, K. Resman Rus, T. Vesnaver Vipotnik, V. Fabjan Vodusek, A. Vizjak, J. Pizem, M. Petrovec, and T. Avsic Zupanc. 2016. Zika Virus Associated with Microcephaly. New England Journal of Medicine 374 (10):951-8. doi: 10.1056/NEJMoa1600651.

Mor, G. 2016. Placental Inflammatory Response to Zika Virus May Affect Fetal Brain Development. American Journal of Reproductive Immunology 75 (4):421-2. doi: 10.1111/aji.12505.

Musso, D. 2015. Zika Virus Transmission from French Polynesia to Brazil. Emerging Infectious Diseases 21 (10):1887. doi: 10.3201/eid2110.151125.

Musso, D., T. Nhan, E. Robin, C. Roche, D. Bierlaire, K. Zisou, A. Shan Yan, V. M. CaoLormeau, and J. Broult. 2014. Potential for Zika Virus Transmission through Blood Transfusion Demonstrated During an Outbreak in French Polynesia, November 2013 to February 2014. Eurosurveillance 19 (14). 
Review of Science: Zika Virus

Musso, D., E. J. Nilles, and V. M. Cao-Lormeau. 2014. Rapid Spread of Emerging Zika Virus in the Pacific Area. Clinical Microbiology and Infection 20 (10):O595-6. doi: 10.1111/1469-0691.12707.

Musso, D., C. Roche, T. X. Nhan, E. Robin, A. Teissier, and V. M. Cao-Lormeau. 2015. Detection of Zika Virus in Saliva. Journal of Clinical Virology 68:53-5. doi: 10.1016/j.jcv.2015.04.021.

Musso, D., C. Roche, E. Robin, T. Nhan, A. Teissier, and V. M. Cao-Lormeau. 2015. Potential Sexual Transmission of Zika Virus. Emerging Infectious Diseases 21 (2):359-61. doi: 10.3201/eid2102.141363.

National Institute of Allergy and Infectious Diseases (NIAID). 2016. NIAID Research Approach to Zika Virus. https://www.niaid.nih.gov/topics/Zika/ResearchApproach/Pages/default.aspx. Accessed $04 / 14 / 16$.

National Science Foundation (NSF). 2016. National Science Foundation Issues Call for Zika Virus Proposals. http://www.nsf.gov/news/news_summ.jsp?cntn_id=137621. Accessed $04 / 14 / 16$.

Nierenberg, C. 2016. How Zika Virus Spreads: Chain of Events Explained. LiveScience http://www.livescience.com/53566-how-zika-spreads-chain-of-events.html. Accessed $02 / 02 / 16$.

Oehler, E., L. Watrin, P. Larre, I. Leparc-Goffart, S. Lastere, F. Valour, L. Baudouin, H. Mallet, D. Musso, and F. Ghawche. 2014. Zika Virus Infection Complicated by Guillain-Barre Syndrome--Case Report, French Polynesia, December 2013. Eurosurveillance 19 (9). 
Oliveira Melo, A. S., G. Malinger, R. Ximenes, P. O. Szejnfeld, S. Alves Sampaio, and A. M. Bispo de Filippis. 2016. Zika Virus Intrauterine Infection Causes Fetal Brain Abnormality and Microcephaly: Tip of the Iceberg? Ultrasound in Obstetrics \& Gynecology 47 (1):6-7. doi: 10.1002/uog.15831.

Oster, A. M., K. Russell, J. E. Stryker, A. Friedman, R. E. Kachur, E. E. Petersen, D. J. Jamieson, A. C. Cohn, and J. T. Brooks. 2016. Update: Interim Guidance for Prevention of Sexual Transmission of Zika Virus - United States, 2016. MMWR. Morbidity and Mortality Weekly Report 65 (12):323-325. doi: 10.15585/mmwr.mm6512e3.

Pan American Health Organization (PAHO). 2015. Epidemiological Alert: Neurological Syndrome, Congenital Malformations, and Zika Virus Infection. Implications for Public Health in the Americas, December 1, 2015. http://www.paho.org/hq/index.php?option=com_docman\&task=doc_view\&Itemid=270\& gid=32405\&lang=en. Accessed 04/01/2016.

Pan American Health Organization (PAHO). 2016a. Case Definitions. Last Modified 04/01/16 http://www.paho.org/hq/index.php?option=com_content\&view=article\&id=11117\&Itemi $\mathrm{d}=41532$ \&lang=en. Accessed 04/09/16.

Pan American Health Organization (PAHO). 2016b. Zika Epidemiological Update - 5 May 2016. http://www.paho.org/hq/index.php?option=com_content\&view=article\&id=11599\&Itemi $\mathrm{d}=41691$. Accessed 05/12/16.

Paz, S., and J. C. Semenza. 2016. El Nino and Climate Change--Contributing Factors in the Dispersal of Zika Virus in the Americas? Lancet 387 (10020):745. doi: 10.1016/s01406736(16)00256-7. 
Review of Science: Zika Virus

Petersen, L. R., and M. P. Busch. 2010. Transfusion-Transmitted Arboviruses. Vox Sanguinis 98 (4):495-503. doi: 10.1111/j.1423-0410.2009.01286.x.

Rudolph, K. E., J. Lessler, R. M. Moloney, B. Kmush, and D. A. Cummings. 2014. Incubation Periods of Mosquito-Borne Viral Infections: A Systematic Review. American Journal of Tropical Medicine and Hygiene 90 (5):882-91. doi: 10.4269/ajtmh.13-0403.

Stein, R. A. 2016. Zika: Where It Has Been, Where It Is Going, and How to Stop It. International Journal of Clinical Practice 70 (3):182-5. doi: 10.1111/ijcp.12792.

Tang, H., C. Hammack, S. C. Ogden, Z. Wen, X. Qian, Y. Li, B. Yao, J. Shin, F. Zhang, E. M. Lee, K. M. Christian, R. A. Didier, P. Jin, H. Song, and G. L. Ming. 2016. Zika Virus Infects Human Cortical Neural Progenitors and Attenuates Their Growth. Cell Stem Cell. doi: 10.1016/j.stem.2016.02.016.

Thomas, D. L., T. M. Sharp, J. Torres, P. A. Armstrong, J. Munoz-Jordan, K. R. Ryff, A. Martinez-Quinones, J. Arias-Berrios, M. Mayshack, G. J. Garayalde, S. Saavedra, C. A. Luciano, M. Valencia-Prado, S. Waterman, and B. Rivera-Garcia. 2016. Local Transmission of Zika Virus - Puerto Rico, November 23, 2015-January 28, 2016. MMWR. Morbidity and Mortality Weekly Report 65 (6):154-8. doi: 10.15585/mmwr.mm6506e2.

Vasconcelos, P. F., and C. H. Calisher. 2016. Emergence of Human Arboviral Diseases in the Americas, 2000-2016. Vector Borne and Zoonotic Diseases. doi: 10.1089/vbz.2016.1952.

Ventura, C. V., M. Maia, B. V. Ventura, V. V. Linden, E. B. Araujo, R. C. Ramos, M. A. Rocha, M. D. Carvalho, R. Belfort, Jr., and L. O. Ventura. 2016. Ophthalmological Findings in Infants with Microcephaly and Presumable Intra-Uterus Zika Virus Infection. Arquivos Brasileiros de Oftalmologia 79 (1):1-3. doi: 10.5935/0004-2749.20160002. 
Waggoner, J. J., and B. A. Pinsky. 2016. Zika Virus: Diagnostics for an Emerging Pandemic Threat. Journal of Clinical Microbiology. doi: 10.1128/jcm.00279-16.

Weaver, D. D., and I. K. Brandt. 1999. Catalog of Prenatally Diagnosed Conditions. Baltimore: Johns Hopkins University Press.

World Health Organization (WHO). 2016a. WHO Statement on the First Meeting of the International Health Regulations (2005) (Ihr 2005) Emergency Committee on Zika Virus and Observed Increase in Neurological Disorders and Neonatal Malformations. http://www.who.int/mediacentre/news/statements/2016/1st-emergency-committeezika/en/. Published 02/01/16. Accessed 04/12/16.

World Health Organization (WHO). 2016b. Zika Virus Fact Sheet. Updated Feb 2016. http://www.who.int/mediacentre/factsheets/zika/en/ Accessed 02/26/16.

World Health Organization (WHO). 2016c. Zika Virus Microcephaly and Guillain-Barre Syndrome Situation Report 7 April 2016. http://apps.who.int/iris/bitstream/10665/204961/1/zikasitrep_7Apr2016_eng.pdf?ua=1. Accessed 04/09/16.

Zanluca, C., and C. N. D. dos Santos. 2016. Zika Virus - an Overview. Microbes and Infection. doi: 10.1016/j.micinf.2016.03.003.

Zanluca, C., V. C. Melo, A. L. Mosimann, G. I. Santos, C. N. Santos, and K. Luz. 2015. First Report of Autochthonous Transmission of Zika Virus in Brazil. Memorias do Instituto Oswaldo Cruz 110 (4):569-72. doi: 10.1590/0074-02760150192.

Zika Virus Infection: Global Update on Epidemiology and Potentially Associated Clinical Manifestations. 2016. Weekly Epidemiological Record 91 (7):73-81. 
Review of Science: Zika Virus: Figures and Tables

\section{Review of Science for Science Librarians:}

\section{The Challenge of the Zika Virus: An Emerging Arbovirus Disease}

Figures and Tables

Fig 1. Timeline of global Zika virus spread, 1947-2016. Source: World Health Organization. http://www.who.int/bulletin/online_first/16-171082/en/. Accessed 04/16/16. Used with permission.
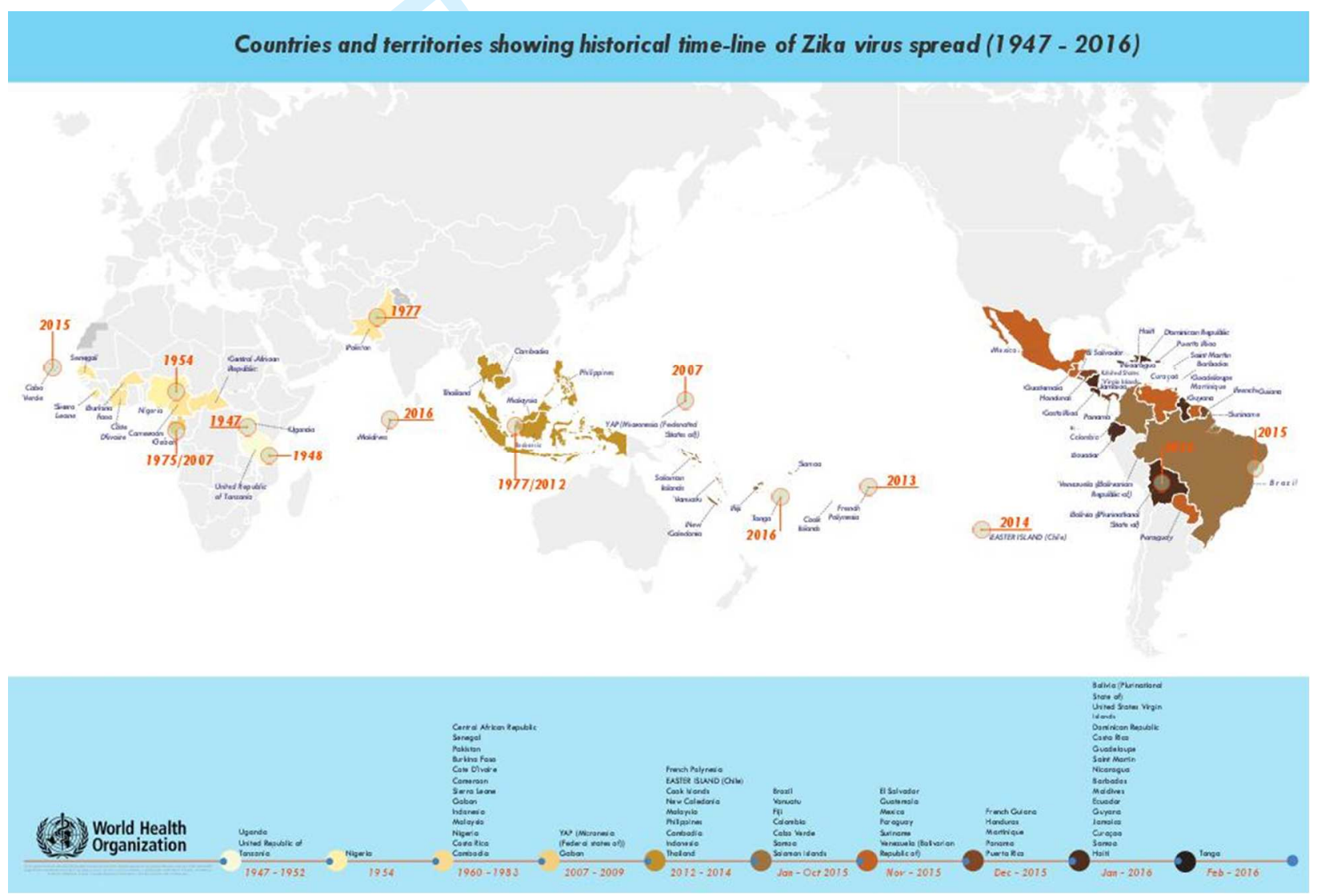
Review of Science: Zika Virus: Figures and Tables

Fig. 2. The distribution of Zika virus in the Americas, 2015-2016. Source: World Health Organization. http://www.who.int/emergencies/zika-virus/situation-report/7-april-2016/en/ Accessed 04/15/16. Used with permission.

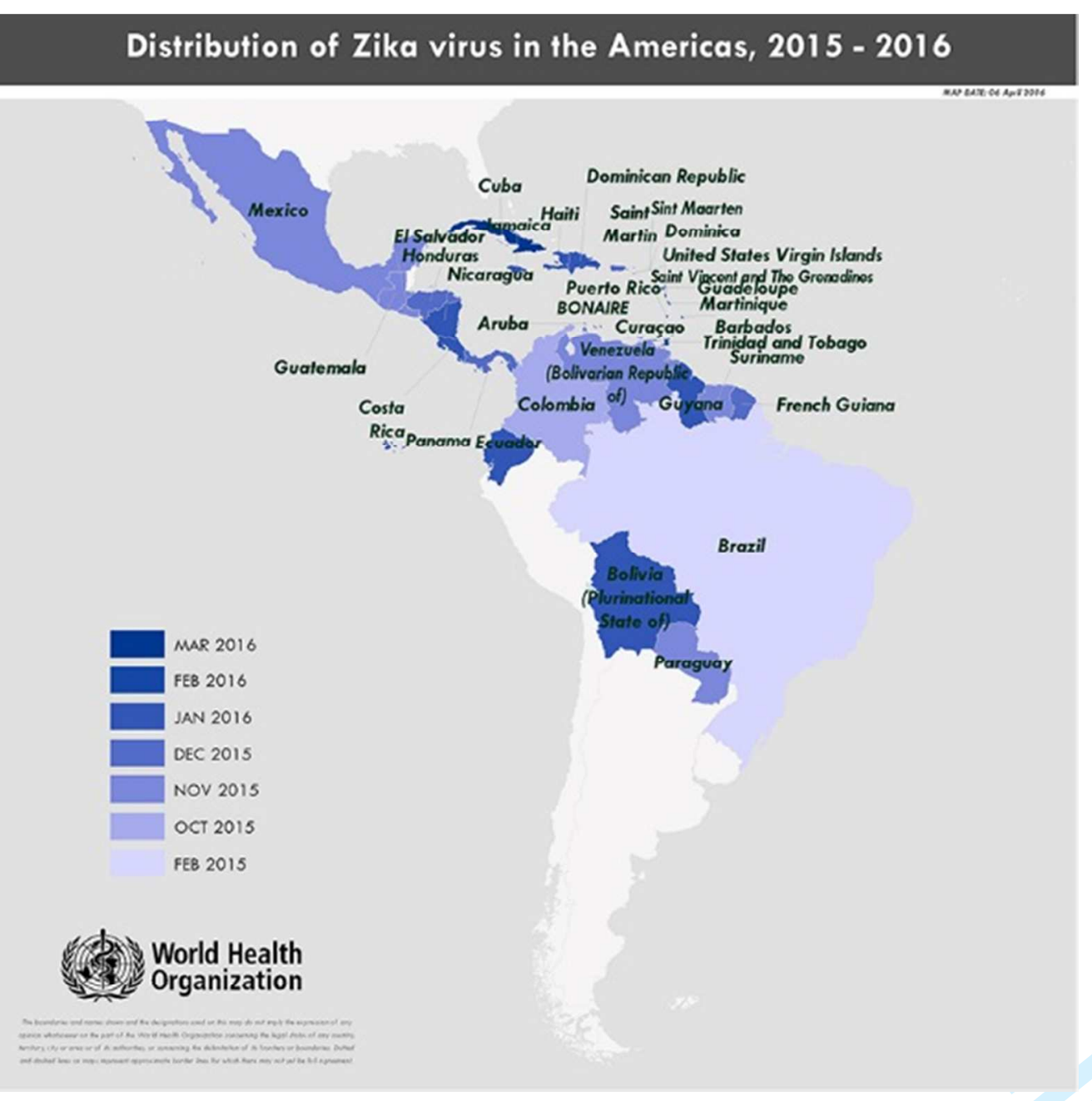


Review of Science: Zika Virus: Figures and Tables

Fig 3. Transmission electron micrograph (TEM) of the Zika virus. Source: Cynthia Goldsmith,

Centers for Disease Control and Prevention (http://phil.cdc.gov/phil/details.asp?pid=20541).

Accessed 04/15/16. Used with permission.

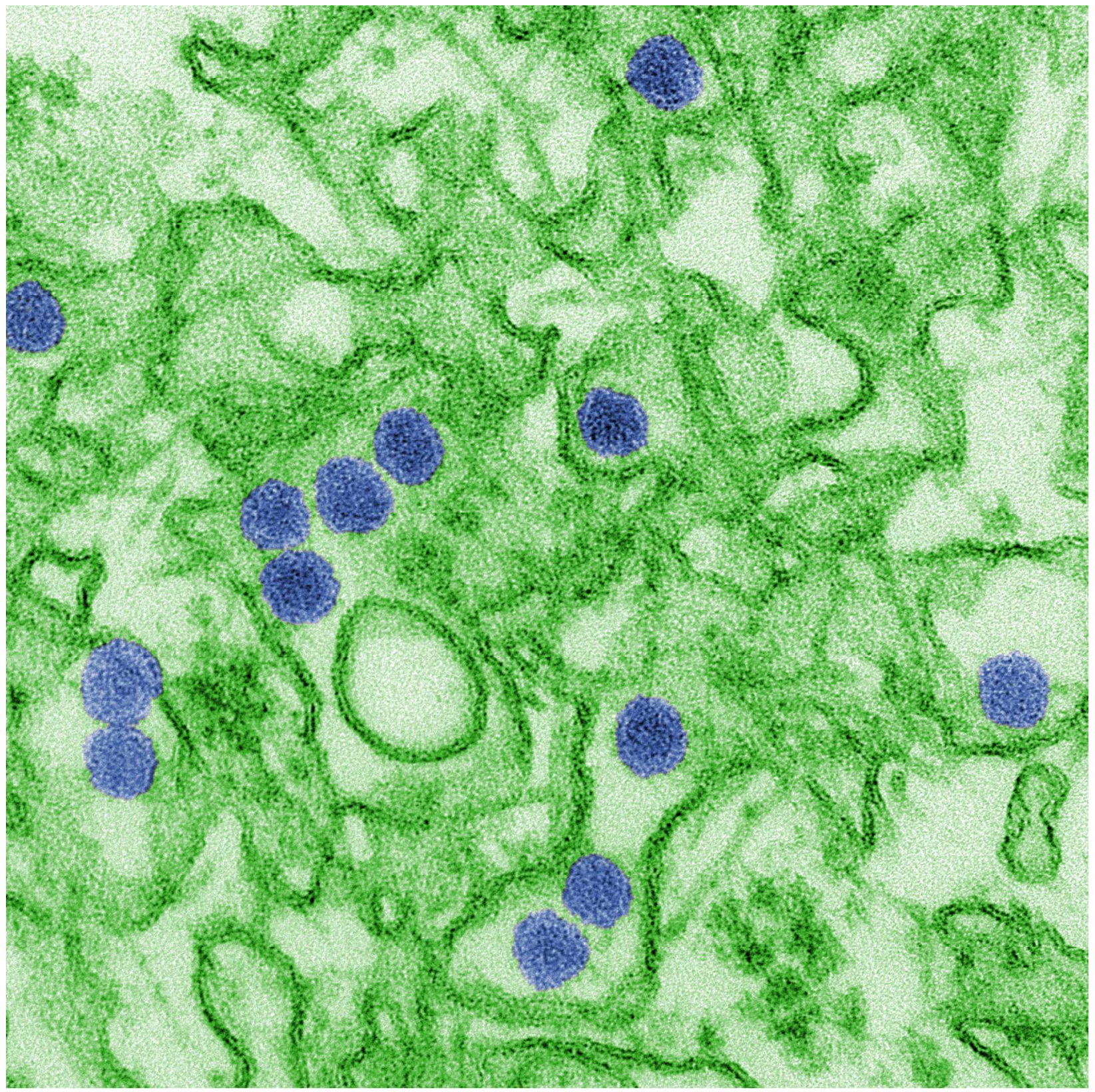

URL: http://mc.manuscriptcentral.com/scitechlibs Email: tstankus@uark.edu 
Table 1. Selected websites for clinical, epidemiological, and research information on Zika Virus and Zika Virus outbreaks.

\begin{tabular}{|c|c|}
\hline Resource & Description \\
\hline $\begin{array}{l}\text { Centers for Disease Control and Prevention (CDC): Zika } \\
\text { Virus } \\
\text { http://www.cdc.gov/zika/index.html }\end{array}$ & $\begin{array}{l}\text { Provides comprehensive } \\
\text { information on all aspects of Zika } \\
\text { Virus, including weekly } \\
\text { epidemiologic updates. Operated } \\
\text { under the US Department of } \\
\text { Health \& Human Services. }\end{array}$ \\
\hline $\begin{array}{l}\text { Disaster Information Management Resource Center } \\
\text { (DIMRC): Zika Virus Health Information Resource } \\
\text { Guide } \\
\text { https://sis.nlm.nih.gov/dimrc/zikavirus.html }\end{array}$ & $\begin{array}{l}\text { Includes an extensive listing of } \\
\text { resources on Zika virus outbreaks } \\
\text { from US and international sources. } \\
\text { The DIMRC is part of the US } \\
\text { National Library of Medicine. }\end{array}$ \\
\hline $\begin{array}{l}\text { European Centre for Disease Prevention and Control } \\
\text { (ECDC): Zika Virus Infection } \\
\text { http://ecdc.europa.eu/en/healthtopics/zika virus } \\
\text { infection/Pages/index.aspx }\end{array}$ & $\begin{array}{l}\text { Provides mosquito maps for the } \\
\text { EU, risk assessment documents, } \\
\text { epidemiological updates, and } \\
\text { news. The ECDC is an } \\
\text { independent European Union } \\
\text { agency. }\end{array}$ \\
\hline $\begin{array}{l}\text { Health Map: Zika Outbreak } \\
\text { http://www.healthmap.org }\end{array}$ & $\begin{array}{l}\text { Features interactive global maps } \\
\text { with moveable timelines and links } \\
\text { to local, regional, \& national news } \\
\text { sources. From Boston Children's } \\
\text { Hospital, Boston, MA, USA. }\end{array}$ \\
\hline $\begin{array}{l}\text { MedlinePlus: Zika Virus } \\
\text { https://www.nlm.nih.gov/medlineplus/zikavirus.html }\end{array}$ & $\begin{array}{l}\text { Offers high-quality, authoritative } \\
\text { information on Zika virus for } \\
\text { researchers, healthcare } \\
\text { professionals, students, and the } \\
\text { general public. From the US } \\
\text { National Library of Medicine. }\end{array}$ \\
\hline $\begin{array}{l}\text { National Institute of Allergy and Infectious Diseases } \\
\text { (NIAID): Zika Virus } \\
\text { https://www.niaid.nih.gov/topics/Zika/Pages/default.aspx }\end{array}$ & $\begin{array}{l}\text { Contains information and reports } \\
\text { on current Zika research. The } \\
\text { NIAID is one of the } 21 \text { institutes } \\
\text { of the US National Institutes of } \\
\text { Health. }\end{array}$ \\
\hline $\begin{array}{l}\text { Pan American Health Organization (PAHO): Zika Virus } \\
\text { Infection } \\
\text { http://www.paho.org/hq/ }\end{array}$ & $\begin{array}{l}\text { Provides information, news and } \\
\text { epidemiological updates for the } \\
\text { general public and health } \\
\text { authorities. PAHO is the regional } \\
\text { office of the World Health } \\
\text { Organization. }\end{array}$ \\
\hline $\begin{array}{l}\text { Program for Monitoring Emerging Diseases/ProMed- } \\
\text { mail }\end{array}$ & $\begin{array}{l}\text { International forum for rapid } \\
\text { reporting of infectious disease }\end{array}$ \\
\hline
\end{tabular}


Review of Science: Zika Virus: Figures and Tables

\begin{tabular}{|l|l|}
\hline http://www.promedmail.org/ & $\begin{array}{l}\text { outbreaks and environmental } \\
\text { exposures. From the International } \\
\text { Society for Infectious Diseases. }\end{array}$ \\
\hline $\begin{array}{l}\text { PubMed } \\
\text { http://www.ncbi.nlm.nih.gov/pubmed }\end{array}$ & $\begin{array}{l}\text { Provides citations, abstracts, and } \\
\text { often the full text, for peer- } \\
\text { reviewed journal articles. From the } \\
\text { US National Library of Medicine. }\end{array}$ \\
\hline $\begin{array}{l}\text { World Health Organization (WHO): Zika } \\
\text { http:/www.who.int/en/ }\end{array}$ & $\begin{array}{l}\text { Provides a wealth of resources and } \\
\text { publications on Zika virus, } \\
\text { including periodic situation } \\
\text { reports. The WHO is an agency of } \\
\text { the United Nations. }\end{array}$ \\
\hline
\end{tabular}


Table 2. Zika Virus and its taxonomic relatives. Excerpted from: International Committee on Taxonomy of Viruses 2014. http://www.ictvonline.org/virustaxonomy.asp. Accessed 04/15/16.

\begin{tabular}{|c|}
\hline Family: Flaviridae \\
\hline Genus: Flavirirus (53 species) \\
\hline Species (Selected): \\
\hline Dengue Virus \\
\hline Japanese encephalitis virus \\
\hline St. Louis encephalitis virus \\
\hline Tick-borne encephalitis virus \\
\hline West Nile virus \\
\hline Yellow fever virus \\
\hline Zika virus \\
\hline Family: Togaviridae \\
\hline Genus: Alphavirus (31 species) \\
\hline Species (Selected): \\
\hline Chikungunya virus \\
\hline Eastern equine encephalitis virus \\
\hline Sindbis virus \\
\hline Venezuelan equine encephalitis virus \\
\hline Western equine encephalitis virus \\
\hline Genus: Rubivirus (1 species) \\
\hline Species: \\
\hline Rubella virus \\
\hline
\end{tabular}


Table 3. The National Institute of Allergy and Infectious Diseases' research approach to Zika

Virus. Adapted from: National Institute of Allergy and Infectious Diseases

https://www.niaid.nih.gov/topics/Zika/ResearchApproach/Pages/default.aspx Accessed 04/16/16.

Used with permission.

In Jan 2016, the NIAID issued a call for Zika-related research proposals in the following areas:

- Development of sensitive, specific, and rapid clinical diagnostic tests for Zika virus

- Development of Zika-specific antivirals, as well as broad spectrum antivirals that would be effective against multiple flaviviruses

- Development and testing of vaccines to protect against Zika virus infection

- Virology research to understand Zika virus infection, replication, pathogenesis, and transmission, as well as the biology of the mosquito vectors

- Development of animal models for the study of the progression of Zika infections in humans

- Studies on the evolution and emergence of Zika virus, including the identification of factors that affect host-range and virulence

- Surveillance studies of the distribution and natural history of Zika virus

- Evaluation of immune responses to Zika and co-existing flaviviruses, especially dengue virus and yellow fever virus

Additionally, in Feb 2016, the National Institutes of Health issued a call for proposals for studies investigating the effect of the Zika virus on reproduction, pregnancy, and the developing fetus. 